\title{
Evidence of uptake of different pollutants in plants harvested from soil treated and fertilized with organic materials as source of soil nutrients from developing countries
}

\author{
J. O. Olowoyo ${ }^{1,2^{*}}$ and L. L. Mugivhisa ${ }^{1}$
}

\begin{abstract}
The use of organic materials as soil nutrients to improve agricultural production is well documented. However, these organic materials may contain toxic pollutants that may bio-accumulate in plant tissues and eventually be consumed by humans. There is a misconception about the use of organic materials (sludge, urine, human waste and urban waste) in agriculture and organic farming. The review work examined the sources and uses of organic material in agriculture from developing countries and the dangers posed by the use of polluted organic materials in agriculture. The review examined through literature the availability and uptake of pollutants in crops that are cultivated from farming activities using organic materials. The review established the possibility of uptake of pollutants from treated waste materials that are used for farming. Some of the pollutants that can be bio-accumulated by plants when cultivated on soil containing these pollutants were documented. The review concluded by establishing the need to create awareness on the possible health risks associated with the use of organic materials if the materials used were polluted. The review also highlighted the importance of educating peasant farmers on the dangers associated with collecting waste materials from untreated sources.
\end{abstract}

Keywords: Organic materials, Pollutants, Crops, Peasant farmers, Education

\section{Introduction}

The use of organic materials (compost, waste, urine, human waste, wastewater and bio solids) in farming is well documented in literature [1-4]. The aim is to improve soil fertility and nutrient supply to crops. However, some organic materials have been documented to contain toxic pollutants and the cumulative loading of these toxic pollutants in agricultural soil may pose significant risk to the ecological functions of soils, plant growth and human health [5].

The use of organic materials in farming should not be misconstrued with organic farming. The European Union (EU) policy [6] which is the first documented

\footnotetext{
${ }^{*}$ Correspondence: woleolowoyo@yahoo.com

${ }^{1}$ Department of Biology, Sefako Makgatho Health Sciences University,

P.O. Box 139, Pretoria 0204, Medunsa, South Africa

Full list of author information is available at the end of the article
}

policy on organic farming described organic farming as a production system that uses farm inputs that are previously derived from organic farming. This involves the use of non-synthetic materials and prohibits the use of any products that are generated from plants, animals and human residues that do not originate from organic farming to improve the fertility of the soil which may lead to an increase in crop production [7-9]. However, this is usually not the case with the use of organic materials in agriculture. Organic materials used for farming especially by peasant farmers are collected from various sources and applied directly to soil for farming purposes.

\section{Sources and uses of organic materials in agriculture from different countries}

In some parts of Asia and Africa, there are few or no documented guidelines on the operation of organic farming and the use of organic materials in agriculture. 
Individuals, especially poor farmers relied on domestic waste without having prior knowledge of their source and impact for agricultural purposes [10]. Organic materials used for farming are usually collected from various sources including street waste, biosolids (human excreta and animal waste), treated and untreated sludge. In India, municipal solid wastes are usually collected from street bins, markets or purchased from the municipal dumpsite and sold informally to peri-urban farmers [11]. In this case, the wastes are applied directly (unsorted) and used for farming with the sole aim of increasing productivity. In Kano, Nigeria, 'taki', is widely used, which is a composition of manure, household waste, street sweepings and ash [12]. From the same area, disposed and unused materials from tanneries and abattoirs have also been used which may also contain an unknown amount of toxic materials such as trace metals and other pollutants such as polycyclic aromatic hydrocarbons (PAHs) and (PCBs) since these contain materials which are swept on the streets.

Generally in Africa, farmers still rely on organic waste in the form of compost emanating either from household wastes that have been deposited in landfill sites or carried out manually by the farmers from their own households. Also, some farmers who have their farms situated next to streams or rivers do benefit directly using the waste water in the form of effluents as a form of irrigation in a bid to reduce the cost of supplying water to their farms and this is common in areas where there is a constant experience of drought due to low annual rainfall $[13,14]$. Recently in South Africa, the introduction of urinary diverting toilets has favoured the use of human urine in agriculture [15]. There is an ongoing research on the use of human faeces as a source of organic amendments and this is still under investigation due to various contaminations that may arise from microbes [16].

This aforementioned practice does not follow the proper guideline that established organic farming. The guidelines for the use of organic waste in agriculture stipulate a proper and strict use of only "safe organic waste" for agriculture [17]. Research has also shown that the use of sludge for agricultural purpose should be reviewed which may call for much stricter limits on values of heavy metals and other emerging contaminants [18]. The main objective in regulating or controlling the use of organic waste for agriculture should stem from the concerns about human health and the protection of the environment.

Regulation and certification might be adopted for farmers intending to export their products internationally. This might be difficult with peasant farmers who are only cultivating a handful portion of hectares of land or engaged in backyard farming just for a livelihood. Peasant and poor farmers are unable to deal with the levels and amounts of toxic compounds that might be present in the organic waste due to lack of knowledge on the adverse effects of these toxic pollutants not only on the environment but eventually on consumers of the end products mostly locally, resulting in regulations therefore only being useful to commercial farmers $[15,19]$.

There are concerns over the agricultural products (crops) emanating from farms cultivated using organic materials for farming and these have been reported in literature. For instance, the use of human and animal wastes (faeces and urine) for the production of food, feed or fertilizer may introduce different pathogens into the crops especially when plants are not cooked before consumption. The plant uptake of pharmaceutical drug residues in soil and the availability of pharmaceutical drugs in animal faeces may impact negatively on the supposed gains that could be gained from the use of the waste [20]. Other emerging pollutants have also been reported in either wastewater, soil, sludge or other forms of waste that may be used for organic farming. The present review will provide an overview on what was reported and documented in the literature on the occurrence, behaviour and persistence of organic pollutants in unsorted organic materials used for farming.

\section{Evidence of pharmaceuticals in plants harvested from soil treated with different organic waste or materials such as urine and sludge}

Researchers have reported on the presence and availability of pharmaceutical residues such as antibiotics, analgesics and anti-retroviral drugs in urine, faeces, sludge, soil, wastewater and plant tissues [21-23]. Pharmaceutical drugs are used extensively for mammals (humans and animals) either to improve the reproduction rate, improve the meat quality or to control diseases. After the administration of these drugs, the drugs could either become metabolized or un-metabolized within the system and may be excreted through urine and faeces [24].

Urine accounts for $1 \%$ of the conventional wastewater volumetric flow, but it contributes approximately $64 \%$ of pharmaceuticals, $80 \%$ of nitrogen, and $50 \%$ of phosphorus to waste water body. Pharmaceuticals are partially degraded in the environment and as a result are likely to accumulate in water bodies or sludge. Even though urine can be regarded as an excellent complete fertilizer of plants, which contains phosphorus, nitrogen and potassium, it also contains residues of pharmaceutical products, even after it has been stored for a prolonged period as a treatment step [25]. Hence, the consumption of urine in organic farming goes with the risk of dispersing the pharmaceutical residues onto the agricultural fields [26]. Over the years, it has been reported that the main 
route for pharmaceuticals excretion within the system is through urine, and urine accounts for over $70 \%$ of pharmaceuticals leaving the body and just a few proportion are excreted through the faeces resulting in ecotoxicological risk of about 50\% [25]. The study further reported the presence of antibiotics in urine samples that were stored for over 1 and a half years for use in agriculture [25]. Other studies conducted in two Hebrew universities on human exposure to wastewater-derived pharmaceuticals confirmed that pharmaceutical such as carbamazepine was detected in human urine when the subjects consumed agricultural products irrigated with wastewater. According to the report, carbamazepine was noted as an anticonvulsant drug which was detected in reclaimed wastewater, highly persistent in soil, and could be taken up by crops [27, 28]. Apart from Carbamazepine, longterm persistence of some pharmaceutical drugs such as antibiotics has also been reported to increase the proliferation of antibiotic resistant bacteria, even at low levels in river base flows and may enhance the drug resistance of microorganisms $[27,28]$.

Despite the significant improvement in water treatment technology, certain pharmaceuticals drugs residue may not be removed totally from wastewater that may used for irrigation even after treatment [21, 29]. In South Africa, for example, according to the report from [30], there are about 2, 150,880 people placed on antiretroviral drugs in the fight against HIV/AIDS which makes South Africa the leading country as regards HIV/AIDS pandemic. It is then logical to think that the residue of these drugs may be present in the environment either in the sludge or in wastewater. In a study conducted on the occurrence of anti-retroviral compounds used for HIV treatment in South African surface water, nevirapine, a non-nucleoside reverse transcriptase inhibitor that is widely use for the treatment of HIV as well as the prevention of mother-to-child transmission was detected in all of the surface water samples used in the study and detected in 9 out of the 24 sampling locations [29]. In another study, the presence of this compound was attributed either to its frequent therapeutic use or also to the compound's persistence in the environment [31]. The compound is reported to be non-biodegradable [32]. Similar study conducted by another researchers showed that levels of nevirapine and efavirenz in wastewater used in the study before treatment were as high as 2100 and $17,400 \mathrm{ng} \mathrm{L}^{-1}$ respectively [21]. However, upon treatment, $50 \%$ of the Antiretrovirals (ARVs) were removed which resulted in the concentrations of nevirapine and efavirenz as high as 350 and $7100 \mathrm{ng} \mathrm{L}^{-1}$, respectively. The study further reported that the addition of chlorine did not reduce the concentrations of the antiretroviral drugs from the treated wastewater.
Apart from the antiretroviral drugs, presence of antibiotics in treated wastewater has also been reported. Antibiotics can be released into hospital wastewater due to excretion of used antibiotics and improper disposal of unused or expired antibiotics [33]. This may pose a significant health risk especially causing antibiotic resistance, by promoting the selection of antibiotic resistance genes and antibiotic resistant bacteria which may pose a serious threat to global public health [34, 35]. The study of [36] in 2016 on antibiotics in wastewater reported the presence of ciprofloxacin and metronidazole in waste water released from hospitals both before the treatment and after the treatment of the wastewater in Vietnam which shows that the treatment of the wastewater does not necessarily translate to the removal of the pharmaceutical drugs from this wastewater. Similarly, [37] quantified the levels of ofloxacin (OFC), ciprofloxacin (CI), levofloxacin (LVX), oxytetracycline (OTC), and doxycycline (DOX) in wastewater and reported that the antibiotics accumulated in wastewater, soil and plants and later percolated to groundwater.

Several reports have shown advancement in various methods used for the removal of pharmaceutical drugs from wastewater. However, to the best of our knowledge and as at the time of writing this report, there are no methods reported in literature that have completely removed pharmaceuticals residues from wastewater. The study of [38] showed that both conventional and advanced wastewater treatment plants significantly reduced antibiotic concentrations with an average removal rate from the liquid phase of $92 \%$. However, this does not remove antibiotics in the effluents as the antibiotics were still detected but at a reduced concentration. Ciprofloxacin, sulphamethoxazole, lincomycin and trimethoprim were still detected in the wastewater after treatment [39] in China noted that the advanced wastewater treatment facilities used in treating and removing antibiotics from wastewater did not remove all antibiotics completely. Most of the targeted antibiotics were detected in the secondary and tertiary effluents, with concentrations ranging from 4.8 to 1106.0 and 0.3 to $505.0 \mathrm{ng} \mathrm{L}^{-1}$. From the study, the concentration of fluoroquinolone was relatively high in all the samples (782-1814 ng L ${ }^{-1}$ ). The study concluded that different tertiary treatment processes showed discrepancy in antibiotics removal. Similarly [40] also reported that removal of antibiotics in wastewater by enzymatic treatment with fungal laccase did not reduce the load of antibiotics; however, the addition of syringaldehyde enhanced the degradation of 32 out of the 38 antibiotics by $50 \%$ after $24 \mathrm{~h}$.

With the presence of antibiotics in wastewater which may be used for irrigation, plants can bio-accumulate and store these antibiotics in their tissues $[41,42]$. The 
plant uptake, translocation and bio-accumulation of antibiotics in the edible parts of food crops and fodders have been reported [43-45]. Hussain et al. [37] conducted a study on accumulation of residual antibiotics in the vegetables irrigated by pharmaceutical wastewater and reported that ofloxacin, ciprofloxacin, levofloxacin, oxytetracycline and doxycycline were detected in soil and vegetables collected within the close vicinity of the pharmaceutical industry. The order of pharmaceuticals contamination from the vegetables was in the order leaves $>$ stem/shoot $>$ root $>$ fruit. Similarly, from the study of [46] on the reuse of treated wastewater in agriculture, lettuce leaves showed very high bioconcentration values for caffeine, carbamazepine, and sulfamethoxazole and hormones, indicating that these three compounds can easily accumulate in the leaves after translocation from lettuce roots to leaves. From the same study using tomato plants, all the pharmaceutical products were only detected in the roots. Other studies conducted with the presence of pharmaceuticals in crops are shown in Table 1.

However, it is important to note that the translocation and uptake of these pharmaceutical residues by plants are governed by various factors such as the soil $\mathrm{pH}$, soil organic matter content and the redox potential of the soil. Goldstein et al. [54], reported that factors affecting the uptake of pharmaceuticals by crops irrigated with treated wastewater, includes parameters such as plant physiology, soil physical and chemical properties and also water quality. Sabourin et al. [41] had initially suggested that there might be little risk of pharmaceuticals uptake into vegetable crops, if produced according to current mandated regulations that specify a 1-year offset between biosolid application and crop harvest.
Polycyclic aromatic hydrocarbons (PAHs) and polychlorinated biphenyls (PCBs) in plants harvested from soil treated with organic waste

The presence of PAHs in the environment may be from both natural and anthropogenic sources and may remain in the environment (air, water and soil) for a prolonged period of time, with the later acting as the major source of the PAHs in the environment $[55,56]$. PAHs arise due to incomplete combustion of fossil fuels during heating processes, waste incineration and from automobile exhausts $[57,58]$. They are carcinogenic compounds and many studies have been carried out to identify sources of exposure in human beings. Among those reported in literature to be carcinogenic are benzoanthracene, benzofluoranthene, benzopyrene and dibenzoanthracene [59-61].

Gaseous deposition was reported to be the main pathway of PAHs' presence in plants and this takes place during the opening and closing of stomata. However, a direct relationship between soil and plant PAH concentrations have also been observed, indicating a possible soil uptake and translocation within the plant tissues from contaminated soils [62].

PAHs are frequently found in sludge at relatively high concentrations: $7.8-13.3 \mathrm{mg} \mathrm{kg}^{-1}[63,64]$. In China, more than $1.9 \times 10^{4}$ hectares of farmland was contaminated by PAHs after long-term sewage irrigation [65]. In countries where there are low temperatures and frequent soil freeze thawing, the degradation of PAHs in soil is usually very slow and this may lead to high toxicity of residual PAHs in surface soil, which is harmful to the ecological environment and may contaminate agricultural products [66]. From most developing countries, where waste management is still a serious problem, application and disposal of sludge are done directly on the

Table 1 Pharmaceuticals in plants harvested in soil amended with organic materials

\begin{tabular}{|c|c|c|c|c|}
\hline Crops & Pharmaceuticals & $\begin{array}{l}\text { Organic amendments/planting } \\
\text { method }\end{array}$ & Impact & Authors \\
\hline Lycopersicum esculentus & $\begin{array}{l}\text { Sulfamethoxazole and trimethoprim; } \\
\text { diclofenac }\end{array}$ & $\begin{array}{l}\text { Spiked water used for irrigation; irri- } \\
\text { gation from municipal wastewater } \\
\text { treatment plants }\end{array}$ & $\begin{array}{l}\text { Reduce the soluble solids and } \\
\text { carbohydrate content; health risk } \\
\text { to consumers }\end{array}$ & {$[45,47]$} \\
\hline Lactuca sativa & $\begin{array}{l}\text { Carbamazepine and diclofenac; } \\
\text { ciprofloxacin; sulfamethoxazole, } \\
\text { erythromycin, cefuroxime and } \\
\text { trimethoprim }\end{array}$ & $\begin{array}{l}\text { Wastewater for irrigation; hospital } \\
\text { waste water }\end{array}$ & $\begin{array}{l}\text { Presence of pharmaceuticals in the } \\
\text { leaves; high concentrations of } \\
\text { antibiotics in the leaves }\end{array}$ & {$[48,49]$} \\
\hline Spinacia oleracea & Tetracycline & Sludge and municipal wastewater & High concentrations in leaves & {$[50]$} \\
\hline Raphanus raphanistrum & $\begin{array}{l}\text { Sulfamethoxazole, norfloxacin and } \\
\text { doxycycline }\end{array}$ & Manure & $\begin{array}{l}\text { High concentrations in leaves and } \\
\text { roots }\end{array}$ & {$[51]$} \\
\hline Solanum tuberosum & Sulfamethazine & Manure & Shoots and tuber & {$[52]$} \\
\hline Zeamays & Sulfamethazine & Manure & Shoots & {$[52]$} \\
\hline Daucus carota & Tricolsan and triclocarban & Biochar amended & Root core & [53] \\
\hline
\end{tabular}


field that may contaminate the receiving soil intended for agriculture production.

Reports from literature have suggested that soils are contaminated with PAHs either because of sludge application or through anthropogenic sources and may pose serious danger for farming because plants may take up PAHs and bio-accumulate them in other plant tissues [62, 66-68]. The known and reported pathway for the uptake of PAHs in plants includes root uptake from soil solution, followed by translocation from roots to shoots during transpiration and absorption either through the plant roots or through shoots of volatilized organics from the surrounding air by shoots [69]. The other major uptake from contaminated soil and dust may be retained in the cuticle or penetrate through uptake and transport in oil channels that are found in some oil-containing plants such as carrots [70-72]. It should be noted that the 2-4 ring structured and lower molecular weight PAHs are more likely to be taken up than those with higher molecular weight [73]. The PAHs with high molecular weight are mostly retained in plant roots and PAHs are lipid soluble $[74,75]$.

A study conducted by [67] 2002 showed presence of PAHs in soil and were detected in all plants grown in contaminated soils but low when compared to the levels in the soil except from peeled potatoes. The study further stated that root uptake was the main pathway for high molecular weight PAHs. Kacálková and Tlustoš [72] further reported on high phenanthrene concentration in aboveground biomass of sunflower and significantly high levels of pyrene in maize roots. In a similar study conducted in India on the presence of PAHs in vegetables and fruits, high concentrations of PAHs such as benzoanthracene, benzopyrene, benzofluoranthene and benzofluoranthene was recorded in cabbage $(8.34 \mu \mathrm{g} \mathrm{kg}-1)$, which turned out to be more than in any of the other fruit vegetables. Dietary exposure of PAHs ranging from 0.20 to $0.85 \mu \mathrm{g} \mathrm{p}^{-1}$ day $^{-1}$ was further reported in the study [68].

In addition, the presence of PCBs in plants cultivated organically has also been reported in literature. Presence of PCBs in the environment is directly linked to man and usually referred to as man-made organic chemicals that consist of carbon, hydrogen and chlorine atoms. They can also remain for long periods recycling between air, water and soil. PCBs have been linked to immune system disorders, dermatological problems, reproductive abnormalities, neurobehavioral effects and cancer although the main reason for the cause and effect relationships are difficult to prove, hence it may remain inconclusive at this stage [76]. The production of PCBs and many organochlorine compounds has been banned widely for many years in many countries such as America, Europe and other parts of the world, but there are traces of these PCBs in the environment which remain as contaminants both for the environment and food because of their longterm persistence and mobility $[77,78]$.

Just like the PAHs, PCBs accumulation in plants can occur through root uptake and may be translocated to upper plant parts. Atmospheric deposition that involves uptake of both wet and dry contaminated particulates onto exposed plant surfaces and through uptake of airborne vapours by aerial plant parts via the stomata has been documented as another pathway [79]. The study conducted by [80] in Poland showed that PCBs can still be detected in soil and vegetables either from organic or conventional farming. The result from that study further showed that PCBs in beets harvested from organic farm were high when compared with conventional farming system used. Similarly, the study of [81] also showed a significant difference in the concentrations of PCBs in milk of goats that grazed on polluted sites when compared to the control sites. From the report, the concentrations of the studied PCBs were more than the recommended limit set by the European Union. The study linked the presence of PCBs in this milk to its presence in plants consumed by the goats. This further showed that these pollutants can be transferred from soil to plants and finally to consumers on top of the food chain. Table 2 also provides information on other plants and presence of the PAHs, PCBs and PFCs.

\section{Heavy metals in agricultural products harvested from soil treated with organic materials}

The presence of trace metals in the environment may either come from natural or anthropogenic sources. The natural sources include weathering of rocks, erosion and the nature of the soil while the anthropogenic sources may be as a result of activities such as the type of fertilizers, nature of the organic manure, solid waste disposal, smelting, vehicular emission and emissions from industries [88]. An increase in the concentrations of trace metals in the environment has been a serious concern recently [8]. The increase especially from developing countries might be because of various developmental programmes that are embarked upon by these countries. With the increase of trace metals in the environment, they are thus present in air, water and soil. Major problem associated with trace metals in the environment is their non-biodegradable nature and as a result they may remain within the ecosystem for a very long period.

According to [89], food chain is one of the most important human exposure pathways to heavy metals after inhalation and dermal absorption. Generally, trace metals along with other essential nutrients from the soil are translocated to different parts of the plants, which may 
Table 2 Evidence of PAH, PCB and PFC in crops harvested from soils treated with organic materials

\begin{tabular}{|c|c|c|c|}
\hline Crops & $\mathrm{PAH}, \mathrm{PCB}$ and PFC & $\begin{array}{l}\text { Organic amendment/ } \\
\text { planting method }\end{array}$ & Authors \\
\hline Agricu bisporus & Anthracene, pyrene, fluoranthene, and phenanthrene & Compost & {$[82]$} \\
\hline Lycopersicum esculentus & Dimethyphthalate and diethylphthalate & Biosolids & {$[83]$} \\
\hline Cucumis sativus & \multirow{3}{*}{$\begin{array}{l}\text { Phenantherene,pyrene, flouranthene, benzo[a] anthracene, chrysene, indeno[1,2,3,cd] } \\
\text { pyrene, benzo[a]pyrene }\end{array}$} & \multirow[t]{3}{*}{ Rhizophere soil } & \multirow[t]{3}{*}[84]{} \\
\hline Beta vulgaris L. & & & \\
\hline Allium cepa L. & & & \\
\hline Lactuca sativa & Perfluoroctanoic acid, perfluorooctane sulfonate and perfluorooctane sulphonamide & Compost & {$[85]$} \\
\hline Spinacia oleracea & $\operatorname{Benzo}(k)$ flouranthene and benzo $[a]$ pyrene & Waste-water irrigation & {$[86]$} \\
\hline Zea mays & Acenaphthene and flourene & Sewage & {$[74]$} \\
\hline Brassica oleracea & Benzo $(k)$ flouranthene and benzo $[a]$ pyrene & Waste-water irrigation & {$[86]$} \\
\hline Daucus carota & Perfluoroctanoic acid, perfluorooctane sulfonate and perfluorooctane sulphonamide & Compost & {$[85]$} \\
\hline Capsicum annuum & Phenantrene and Benzo[a]antracene & Waste-water irrigation & {$[87]$} \\
\hline
\end{tabular}

affect the physiological, metabolic, and biochemical activities of the plants negatively [90]. However, several literatures have reported and documented the ability of different plants to act either as an excluder or as bioaccumulator of trace metals from the soil [91-93]. In the case of bio-accumulator, it is possible for plants to uptake or translocate these toxic metals from the soil to their tissue and a foliar uptake in some plants is possible [94]. However, with the bio-accumulators, several factors have been suggested that may affect the uptake of toxic trace metals and these factors include the concentration of heavy metals in soils, soil organic matter content (complexion and adsorption rates), soil $\mathrm{pH}$ ( solubility of metals decreases at high $\mathrm{pH}$ and increases at low $\mathrm{pH}$ ), redox potential of the soil (mobility of trace metals depends on their oxidation state), type of the vegetables and species (differences in plant physiology, morphology and anatomy) [95-98].

The practice of organic farming is usually carried out with the use of farmyard manure, sewage sludge and the reuse of treated wastewater for irrigation [99-101]. The farmyard manure have been documented over the years to contain varying concentrations of toxic trace metals which also depend on the source and areas where the farmyard manure were collected $[102,103]$. Over a prolonged period of time and with continuous application of farmyard manure that are contaminated, there may be land contamination by some potentially toxic elements such as arsenic, cadmium, and lead. Zhao et al. [104] demonstrated that the application of cattle manure increased soil organic matter content of the soil leading to high productivity but with an accumulation of heavy metals in corn that was fertilized with that cattle manure. The study conducted by [100] also showed that concentrations of arsenic (As) and cadmium $(\mathrm{Cd})$ in pig manure were higher than their levels in cattle manure. The study further showed that the use of pig manure as soil supplement resulted in high cadmium $(\mathrm{Cd})$ contamination in Gynostemma pentaphyllum, a herbal tea used for the study. It was further noted that there was a positive concentration for cadmium $(\mathrm{Cd})$ in plants and the soil. Hence, the study concluded that the application of some organic fertilizers or animal manures to agricultural soil could increase some potentially toxic elements in soil, which may be detrimental.

The use of treated and untreated wastewater in the urban and peri-urban areas of many developing countries used for irrigation is a common phenomenon [105, 106]. Farmers believed that undiluted wastewater provides nutrients and is cheaper than other water sources. However, the use of improperly treated and untreated wastewater for irrigation may come with serious problems such as the accumulation of heavy metals in agricultural soils and their uptake by food crops, which may pose a serious health risk to consumers of such products especially the local inhabitants [107]. In municipal wastewater treatment plants, human excreta are mixed with other effluents containing toxic metals, organic residues, pharmaceuticals and pathogens [108]. Khan et al. [109] conducted a study in China, and reported that there is a build-up of heavy metals in wastewater-irrigated soils and this also increased the concentrations of trace metals in plants grown on the soil and the values recorded for some trace metals in the plants exceeded the permissible limit for human consumption. Weldegebriel et al. [110] also reported in a study carried out in Ethiopia on the concentrations of trace metals in vegetables that the concentrations of lead $(\mathrm{Pb})$ and cadmium $(\mathrm{Cd})$ in the vegetables used for the study were above the permissible limits for human consumption. Similarly, [99] also reported that higher concentrations of iron $(\mathrm{Fe})$, copper $(\mathrm{Cu})$, chromium $(\mathrm{Cr})$ and zinc $(\mathrm{Zn})$ were found in lettuce, 
radish and carrots irrigated with treated wastewater. The study of [111] even though reported that the levels of cadmium (Cd) exceeded the acceptable limit for agricultural land, the concentrations of the trace metals in soils and vegetables were all below the permissible limits set by [112].

On the other hand, the application of municipal sludge to agricultural land is an attractive option for disposal because of the possibility of improving soil properties and increasing plant productivity with the recycling of valuable components including organic matter [113]. However, the use of sludge may also pose a serious danger for consumers of products coming from soil fertilized with sludge. Sludge has been known in some instances to contain high amounts of toxic metals $[107,114,115]$. Sewage sludge is a by-product of sewage treatment processes and is made up of pathogenic microorganisms, organic and inorganic components [116]. Due to the presence of trace metals in sludge, several documented reports have suggested that it may be necessary to consider differences in metal affinity and tolerance to soil acidity as shown by specific vegetables and fruits before the application of sludge on agricultural soils [93, 117]. Despite different methods used to determine the suitability of a sludge through different treatment options for agricultural purposes, the presence of pathogens and other pollutants found in the sludge remain a matter of concern [118]. The report from a study conducted by [119] in Nigeria showed that the values of lead $(\mathrm{Pb})$ in vegetables planted on soil after the application of sludge exceeded recommended values for human consumption. The study of [120] and [106] recorded huge zinc ( $\mathrm{Zn})$ and cadmium
(Cd) hazard quotients due to the consumption of vegetables harvested on soil treated with sludge for farming activities in India. Presence of trace metals in other crops from different studies are shown in Table 3.

\section{Conclusion}

The use of organic materials in agriculture should not be viewed as organic farming because this practice does not take into account the exclusion of polluted materials in farming. With well-documented information from literature, there is overwhelming evidence that plants may uptake different types of pollutants from soil when cultivated on soils that are polluted or treated with contaminated organic materials. Despite this evidence, the practice and the indiscriminate use of contaminated organic materials for agriculture is on the increase especially from the developing countries. Poor farmers and members of their immediate families are at great risk especially when organic materials are collected from sources that are unknown and are used for farming.

The questions one tends to ask are the followings: who examines the products at the local levels especially for the poor farmers that collect waste on the streets? Are there regulations or information that may guide these peasant farmers on the appropriate use and handling of sludge and waste collected on the streets? How equipped is the present technology as regards the removal of pollutants either from the sludge or wastewater? When the products are not for sale at the international market, who examines their safety for human consumption locally?

Concerted effort should be placed on the awareness, training and education of the peasant farmers and the

Table 3 Evidence of trace metals in crops harvested from soil treated with organic materials

\begin{tabular}{|c|c|c|c|}
\hline Crops & Bioaccumulated trace metals & Organic amendment/planting methodZn & Authors \\
\hline Agaricus bisporus & $\mathrm{Cr}, \mathrm{Mn}, \mathrm{Co}$ and $\mathrm{Zn}$ & Chicken compost & {$[121]$} \\
\hline Lycopersicum esculentus & $\mathrm{Cd}$ and $\mathrm{Hg}$ & Cowdung & {$[122]$} \\
\hline Cucumis sativus & $\mathrm{Cd}, \mathrm{Cu}, \mathrm{Pb}$ and $\mathrm{Zn}$ & Green manure and compost & {$[97]$} \\
\hline Lactuca sativa & $\mathrm{Mn}, \mathrm{Zn}, \mathrm{Cu}$ and $\mathrm{Hg}$ & Shrimp farm effluents & {$[123]$} \\
\hline Spinacia oleracea & $\mathrm{Cd}, \mathrm{Pb}$ and $\mathrm{Zn}$ & $\begin{array}{l}\text { Wastewater and sludge, paper mill sewage, municipal } \\
\text { solid waste }\end{array}$ & {$[124-127]$} \\
\hline Vigna unguiculata & $\mathrm{Cd}, \mathrm{Pb}, \mathrm{Cr}, \mathrm{Zn}$ and $\mathrm{Cu}$ & Waste dump soil & {$[128]$} \\
\hline Raphanus raphanistrum & $\mathrm{Se}, \mathrm{As}$ and $\mathrm{Zn}$ & Municipal solid waste & {$[129]$} \\
\hline Brassica oleracea & $\mathrm{Cr}, \mathrm{Ni}, \mathrm{Cu}, \mathrm{Zn}, \mathrm{Mo}, \mathrm{Cd}$ and $\mathrm{Pb}$ & Sewage sludge and chicken Manure & {$[130]$} \\
\hline Brassica oleracea L. var. Botrytis & $\mathrm{Pb}$ and $\mathrm{Cd}$ & Brewery sludge & {$[131]$} \\
\hline Beta vulgaris L. & $\mathrm{Cd}, \mathrm{Pb}$ and $\mathrm{Zn}$ & Wheat straw and municipalities wastewater & {$[132]$} \\
\hline Abelmoschus esculentus & $\mathrm{Pb}$ & Battery recycling waste & {$[133]$} \\
\hline Capsicum annuum & $\mathrm{Zn}$ & $\begin{array}{l}\text { Treated urban sewage } \\
\text { Yardwaste, sewage sludge and chicken manure }\end{array}$ & $\begin{array}{l}{[134]} \\
{[135]}\end{array}$ \\
\hline Allium cepa L. & $\mathrm{Zn}$ & Home garden & {$[136]$} \\
\hline Allium fistulosum & $\mathrm{Cd}$ and $\mathrm{Pb}$ & Urban waste & [137] \\
\hline
\end{tabular}


public on how, when and the type of organic materials that may be used for agriculture. Improved and renewed efforts should be geared towards the removal of persistent organic pollutants in the environment (Soil, water and wastewater). This may include the introduction of new technology within the waste treatment plants and research into the ability of different plants that can bioaccumulate these pollutants from the soil.

\begin{abstract}
Abbreviations
EU: European Union; PAH: polycyclic aromatic hydrocarbons; PCB: polychlorinated biphenyls; HIV: human immunodeficiency virus; AIDS: acquired immunodeficiency syndrome; OFC: ofloxacin; Cl: ciprofloxacin; LVX: levofloxacin; OTC: oxytetracycline; DOX: doxycycline; As: arsenic; Cd: cadmium; Pb: lead; Fe: iron; Cu: copper; Cr: chromium; Zn: zinc.
\end{abstract}

\section{Acknowledgements}

The authors are very grateful for the funding received from NRF under the CSUR 2017. This has made the exchange programme to the University of Saskatchewan, Saskatoon in Canada possible. The understanding and leave of absence granted to Prof. Olowoyo JO during his short visit to University of Saskatchewan by Sefako Makgatho Health Sciences is greatly appreciated

\section{Authors' contributions}

JOO design the research review which was part of a major project for LLM Ph.D. degree. Both authors were involved in conceptualization, design and the eventual write up of the manuscript. Both authors read and approved the final manuscript.

\section{Funding}

No funding was received for this particular review work.

\section{Availability of data and materials}

Not applicable.

\section{Competing interests}

The authors declare that they have no competing interests.

\section{Author details}

${ }^{1}$ Department of Biology, Sefako Makgatho Health Sciences University, P.O. Box 139, Pretoria 0204, Medunsa, South Africa. ${ }^{2}$ Toxicology Centre, University of Saskatchewan, Saskatoon, Canada.

Received: 11 September 2019 Accepted: 17 September 2019

Published online: 27 December 2019

\section{References}

1. Gomiero T, Paoletti MG, Pimentel D. Energy and environmental issues in organic and conventional agriculture. Crit Rev Plant Sci. 2008;27:239-54

2. Odlarea M, Lindmark J, Ericsson A, Pell M. Use of organic wastes in agriculture. Energy Procedia. 2015;75:2472-6.

3. Seufert V, Ramankutty N. Many shades of gray-the context-dependent performance or organic agriculture. Sci Adv. 2017;3(3):e1602638. https ://doi.org/10.1126/sciadv.1602638.

4. Lee KS, Choe YC. Environmental performance of organic farming: Evidence from Korean small-holder soybean production. J Clean Prod. 2019;211:742-8.

5. Sun S, Sidhu V, Rong Y, Zheng Y. Pesticide pollution in agricultural soils and sustainable remediation methods: a review. Curr Pollut Rep. 2018. https://doi.org/10.1007/s40726-018-0092-x.

6. European Union (EU) Council Regulation (EC) No. 834/2007 of 28 June 2007 on organic production and labelling of organic products and repealing Regulation (EEC) No. 2092/91. OJEU. L 189/1.
7. FiBL \& IFOAM. The World of Organic Agriculture 2014. Frick and Bonn. 2014. Accessed 5 Mar 2014.

8. Olowoyo JO, Mugivhisa LL, Busa NM. Trace metals in soil and plants around a cement factory in Pretoria, South Africa. Pol J Environ Stud. 2015;24(5):2087-93.

9. Muller A, Schader C, Scialabba NE, Brüggemann J, Isensee A, Smith KEPS, Klocke P, Leiber F, Stolze M, Niggli U. Strategies for feeding the world more sustainably with organic agriculture. Nat Commun. 2017. https://doi.org/10.1038/s41467-017-01410-w.

10. Hofman P. Wasted waste-disappearing reuse at the peri-urban interface. Environ Sci Policy. 2013;2013(31):13-22.

11. Nunan F. Urban organic waste markets: responding to change in HubliDharwad India. Habitat Intl. 2000;2000(24):347-60.

12. Asomani-Boateng $R$, Haight M. Reusing organic solid waste in urban farming in African cities: a challenge for urban planners. Third World Planning Review World Plann Rev. 1999;21(4):411-23.

13. Binns JA, Maconachie RA, Tanko Al. Water, and health in urban and periurban food production: the case of Kano Nigeria. Land Degrad Dev. 2003;14:431-44.

14. Maconachie R. Urban growth and land degradation in developing cities: change and challenges in Kano, Nigeria. Hampshire: Ashgate Publishing Limited; 2007.

15. Mugivhisa LL, Olowoyo JO. An assessment of university students and staff perceptions regarding the use of human urine as a valuable soil nutrient in South Africa. Afr Health Sci. 2015;15(3):999-1010.

16. Kutu FR, Muchaonyerwa P, Mnkeni PNS. Complementary nutrient effects of separately collected human faeces and urine on the yield and nutrient uptake of spinach (Spinacia oleracea). Waste Manag Res. 2010;29(5):532-9.

17. Seufert V, Ramankutty N, Foley JA. Comparing the yields of organic and conventional agriculture. Nature. 2012:485:229-32.

18. Suciu NA, Lamastra L, Trevisan M. PAHs content of sewage sludge in Europe and its use as soil fertilizer. Waste Manag. 2015;41:119-27.

19. Rigby D, Caceres D. Organic farming and the sustainability of agricultural systems. Agric Syst. 2001;68:21-40.

20. Furedy C, Chowdrury T. Solid waste reuse and urban agriculture: dilemmas in developing countries. The bad news and the good news. In: Paper presented at Joint Congress of Association of Collegiate Schools of Planning and Association of European Schools of Planning. Toronto. 1996. https://www.cityfarmer.org/Furedy.html.

21. Schoeman C, Mashiane M, Dlamini M, Okonkwo OJ. Quantification of selected antiretroviral drugs in a wastewater treatment works in South Africa using GC-TOFMS. J Chromatogr Sep Techol. 2015;6:272.

22. Sui Q, Cao X, Lu S, Zhao W, Qiu Z, Yu G. Occurrence, sources and fate of pharmaceuticals and personal care products in the groundwater: a review. Emerg Contam. 2015;1:14-24.

23. Shraim A, Diab A, Alsuhaimi A, Niazy E, Metwally M, Amad M, Sioud S, Dawoud A. Analysis of some pharmaceuticals in municipal wastewater of Almadinah Alm, unawarah. Arab J Chem. 2017;10(1):719-29.

24. Paltiel O, Fedorova G, Tadmor XX, Chefetz B. Human exposure to wastewater-derived pharmaceuticals in fresh produce: a randomized controlled trial focusing on carbamazepine. Environ Pollut. 2016:213:308-13.

25. Winker M. Are pharmaceutical residues in urine a constraint for using urine as a fertiliser? Sustain Sanit Practice Issue. 2010;3:18-24.

26. Winker M, Tettenborn F, Faika D, Gulyas H, Otterphol R. Comparison of analytical and theoretical pharmaceutical concentrations in human urine in Germany. Water Res. 2008;42(14):3633-40.

27. Molina-Garcia L, Martìnez-Exposito R, Fernandez-de-Cordova ML, Llorent-Martinez EJ. Determination of the phenolic profile and antioxidant activity of leaves and fruits of Spanish Quercus coccifera. J Chem. 2018. https://doi.org/10.1155/2018/2573270.

28. Watkinson AJ, Murby EJ, Kolpin DW, Costanzo SD. The occurrence of antibiotics in an urban watershed: from wastewater to drinking water. Sci Total Environ. 2009;407(8):2711-23.

29. Wood T, Duvenage CSJ, Rohwer E. The occurrence of anti-retroviral compounds used for HIV treatment in South African surface water. Environ Pollut. 2015;199:235-43.

30. World Health Organization (WHO). Consolidated Guidelines on the use of antiretroviral drugs for treating and preventing HIV infection; Geneva. 2013. https://www.who.int/hiv/pub/guidelines/arv2013 
31. Vanková M. Biodegradability analysis of pharmaceuticals used in developing countries; screening with OxiTop C-110. Tampere University of Applied Sciences. 2010. https://urn.fi/URN:NBN:fi:amk-2010120817546.

32. Coovadia H, Brown HM, Fowler ER, Chipato MG, Moodley TD, Manji K, Musoke P, Stranix-Chibanda L, Chetty V, Fawzi W, Nakabiito C, Msweli L, Kisenge R, Guay L, Mwatha A, Lynn DJ, Eshleman ES, Richardson P, Maldonado P. Efficacy and safety of an extended nevirapine regimen in infant children of breastfeeding mothers with HIV-1 infection for prevention of postnatal HIV-1 transmission (HPTN 046): a randomized, double-blind, placebo-controlled trial. Lancet. 2012;379(9812):221-8.

33. Michael I, Rizzo L, McArdell CS, Manaia CM, Merlin C, Schwartz T, Dagot C, Fatta-Kassinos D. Urban waste water treatment plants as hotspots for the release of antibiotics in the environment: a review. Water Resour. 2013;47:957-93.

34. Kümmerer K. Antibiotics in the aquatic environment-a review-part I. Chemosphere. 2009;4:417-34

35. World Health Organization (WHO). Antimicrobial resistance: global report on surveillance. p. 257. 2014. Publication date: April 2014. Languages: English. ISBN: 9789241564748.

36. Lien LTQ, Hoa NQ, Chuc NTK, Thoa NTM, Phuc HD, Diwan V, Dat NT, Tamhankar AJ, Lundborg CS. Antibiotics in wastewater of a rural and an urban hospital before and after wastewater treatment, and the relationship with antibiotic use - a one year study from Vietnam. Int J Environ Res Public Health. 2016;13(6):588. https://doi.org/10.3390/ijerph1306 0588 .

37. Hussain S, Naeem M, Nawaz CM. Estimation of residual antibiotics in pharmaceutical effluents and their fate in affected areas. Pol J Environ Stud. 2016;1:25. https://doi.org/10.15244/pjoes/61229.

38. Watkinson AJ, Murby EJ, Costanzo SD. Removal of antibiotics in conventional and advanced wastewater treatment: implications for environmental discharge and wastewater recycling. Water Res. 2007;41(18):4164-77.

39. Li XW, Xie YF, Li CL, Zhao HN, Zhao H, Wang N. Investigation of residual fluoroquinolones in a soil-vegetable system in an intensive vegetable cultivation area in Northern China. Sci Total Environ. 2014:46:58-264.

40. Becker D, Giustina SVD, Rodríguez-Mozaz S. Removal of antibiotics in wastewater by enzymatic treatment with fungal laccase-degradation of compounds does not always eliminate toxicity. Bioresour Technol. 2016;219:500-9.

41. Sabourin L, Duenk P, Bonte-Gelok S, Payne M, Lapen DR, Topp E. Uptake of pharmaceuticals, hormones and parabens into vegetables grown in soil fertilized with municipal biosolids. Sci Total Environ. 2012;431:233-6.

42. Tanoue R, Sato Y, Motoyamam M, Nakagawam S, Shinohara R, Nomiyama K. Plant uptake of pharmaceutical chemicals detected in recycled organic manure and reclaimed wastewater. J Agric Food Chem. 2012;60:10203-1021.

43. Wu X, Ernst F, Conkle JL, Gan J. Comparative uptake and translocation of pharmaceutical and personal care products (PPCPs) by common vegetables. Environ Int. 2013;60:15-22

44. Christou A, Antoniou C, Christodoulou C, Hapeshi E, Stavrou I, Michael C, Fatta-Kassinos D, Fotopoulos V. Stress-related phenomena and detoxification mechanisms induced by common pharmaceuticals in alfalfa (Medicago sativa L.) plants. Sci Total Environ. 2016;557-558:652-64.

45. Christou A, Karaolia P, Hapeshi E, Michael C, FattaKassinos D. Longterm wastewater irrigation of vegetables in real agricultural systems: concentration of pharmaceuticals in soil, uptake and bioaccumulation in tomato fruits and human health risk assessment. Water Res. 2017;109:24-34

46. Zheng Z, Yang M, Zeng Y, Wu J, Qiu K Huang $\mathrm{H}$. Changing the perspec tive of off-label drug use in China. BMJ (Blog). 2017. https://blogs.bmj. com/bmj/2016/01/12/zhihua-zheng-et-alchanging-the-perspectiv e-of-off-label-drug-use-in-china/. Accessed 5 Jan 2017.

47. Christou A, Papadavid G, Dalias P, Fotopoulos V, Michael C, Bayona J, Piña B, Fatta-Kassinos D. Ranking of crop plants according to their potential to uptake and accumulate contaminants of emerging concern. Environl Res. 2018. https://doi.org/10.1016/j.envres.2018.12.048.

48. García-Morales MA, Juárez JCG, Martínez-Gallegos S, Roa-Morales G, Peralta E, Lopez EMC, Barrera-Díaz C, Miranda VM, Blancas TT. Pre-treatment of real wastewater from the chocolate manufacturing industry through an integrated process of electrocoagulation and sand filtration. Int J Photoenergy. 2018. https://doi.org/10.1155/2018/21467 51.

49. Azanu D, Styrishave B, Darko G, Weisser J, Clement A. Occurrence and risk assessment of antibiotics in water and lettuce in Ghana. Sci Total Environ. 2017;1:622-3.

50. Migliore L, Godeas F, De Filippis SP, Mantovi P, Barchi D, Testa C, Rubattu $\mathrm{N}$, Brambilla G. Hormetic effect(s) of tetracyclines as environmental contaminant on Zea mays. Environ Pollut. 2010;158(1):129-34.

51. Wang J, Wang $P$, Wang $X$, Zheng $Y$, Xiao $Y$. Use and prescription of antibiotics in primary health care settings in China. JAMA Intern Med. 2014;174(12):1914-20.

52. Dolliver H, Kumar K, Gupta S. Sulfamethazine uptake by plants from manure-amended soil. J Environ Qual. 2007. https://doi.org/10.2134/ jeq2006.0266.

53. Fu Q, Wu X, Ye Q, Ernst F, Gan J. Biosolids inhibit bioavailability and plant uptake of triclosan and triclocarban. Water Res. 2016:102:117-24.

54. Goldstein M, Shenker M, Chefetz B. Insights into the uptake processes of wastewater-borne pharmaceuticals by vegetables. Environ Sci Technol. 2014;48:5593-600.

55. European Food Safety Authority (EFSA). Polycyclic aromatic hydrocarbons in food scientific opinion of the panel on contaminants in the food chain. (Question NEFSA-Q-2007-136). Adopted on 9 June 2008. EFSA J. 2008; 724:1-114.

56. Ashraf MW, Salam A. Polycyclic aromatic hydrocarbons (PAHs) in vegetables and fruits produced in Saudi Arabia. Bull Environ Contam Toxicol. 2012;88(4):543-7.

57. Agency for Toxic Substances and Disease Registry (ATSDR). Public Health Assessment for Los Alamos National Laboratory. Atlanta: U.S. Department of Health and Human Services, Public Health Service. 2005

58. Hsu Y, Harner T, Li H, Fellin P. PAH Measurements in air in the athabasca oil sands region. Environ Sci Technol. 2015. https://doi.org/10.1021/acs. est.5b00178.

59. International Agency for Research on Cancer (IARC). Polynuclear aromatic compounds, part 1. Chemical, environmental and experimental data. IARC monographs on the evaluation of carcinogenic risk of chemicals to humans. Lyon: International Agency for Research on Cancer. 1983.

60. Patowary R, Patowary K, Devi A, Mohan CK, Deka S. Uptake of total petroleum hydrocarbon (TPH) and polycyclic aromatic hydrocarbons (PAHs) by Oryza sativa L grown in soil contaminated with crude oil. Bull Environ Contam Toxicol. 2017. https://doi.org/10.1007/s0012 8-016-1990-5.

61. Pullagurala VR, Rawat S, Adisa IO, Hernandez-Viezcas JA, Peralta-videa J. Plant uptake and translocation of contaminants of emerging concern in soil. Sci Total Environ. 2018;636:1585-96. https://doi.org/10.1016/j. scitotenv.2018.04.375

62. Meudec A, Dussauze J, Deslandes E, Poupart N. Evidence for bioaccumulation of PAHs within internal shoot tissues by a halophytic plant artificially exposed to petroleum-polluted sediments. Chemosphere. 2006;65:474-81. https://doi.org/10.1016/j.Chemosphere.01.058.

63. Kapanen A, Vikman M, Rajasärkkä J, Virta M. Biotests for environmental quality assessment of composted sewage sludge. Waste Manag. 2013;33(6):1451-60.

64. Rhind SM, Kyle CE, Kerr C, Osprey M, Zhang ZL, Duff El, Lilly A, Nolan A, Hudson G, Towers W, Bell J, Coul M, McKenzie C. Concentrations and geographic distribution of selected organic pollutants in Scottish surface soils. Environ Pollut. 2013;182:15-27.

65. Li Z, Sandau CD, Romanoff LC, Caudill SP, Sjodin A, Needham LL, Patterson DG. Concentration and profile of 22 urinary polycyclic aromatic hydrocarbon metabolites in the US population. Environ Res. 2008;107:320-31.

66. Zhao H, Yin C, Chen M, Wang W, Jefferies C, Shan B. Size distribution and diffuse pollution impacts of PAHs in street dust in urban streams in the Yangtze River Delta. J Environ Sci (China). 2009;21:162-7. https://doi. org/10.1016/S1001-0742(08)62245-7.

67. Fismes J, Perrin-Ganier C, Empereur-Bissonnet P, Morel JL. Soil-to-root transfer and translocation of polycyclic aromatic hydrocarbons by vegetables grown on industrial contaminated soils. J Environ Qual. 2002;31(5):1649-56.

68. Duan X, Shen G, Yang H, Tian J, Wei F, Gong J, Zhang J. Dietary intake polycyclic aromatic hydrocarbons (PAHs) and associated cancer risk in 
a cohort of Chinese urban adults: inter- and intra-individual variability. Chemosphere. 2016;144:2469-75.

69. Gworek B, Klimczak K, Kijeńska M, Gozdowski D. Comparison of PAHs uptake by selected monocotyledons and dicotyledons from municipal and industrial sewage sludge. Environ Sci Pollut Res Int. 2016;23(19):19461-70.

70. Topp E, Scheunert I, Attar A, Korte F. Factors affecting the uptake of 14C labelled organic chemicals by plants from soil. Ecotoxicol Environ Safety. 1986;11:219-28.

71. Duarte-Davidson R, Jones KC. Screening the environmental fate of organic contaminants in sewage sludge applied to agricultural soils. II. The potential for transfers to plants and grazing animals. Sci Total Environ. 1996:185:59-70.

72. Kacálková L, Tlustoš P. The uptake of persistent organic pollutants by plants. Open Life Sci. 2011;6:223-35.

73. Li H, Ma Y. Field study on the uptake, accumulation, translocation and risk assessment of PAHs in a soil-wheat system with amendments of sewage sludge. Sci Total Environ. 2016;1:560-1.

74. Lin H, Shuangcheng TAO, Zuo Q, Coveney R. Uptake of polycyclic aromatic hydrocarbons by maize plants. Environ Pollut. 2007;148:614-9.

75. Salehi-Lisar SY, Deljoo S. The physiological effect of fluorene on Triticum aestivum, Medicago sativa, and Helianthus annus. Cogent Food Agric. 2015;1:1020189.

76. Longnecker MP, Rogan WJ, Lucier G. The human health effects of DDT (dichlorodiphenyltrichloroethane) and PCBs (polychlorinated biphenyls) and an overview of organochlorines in public health. Annu Rev of Public Health. 1997:18:211-44.

77. Orlinskii D, Priputina I, Popova A, Shalanda A, Tsongas T, Hinman G, Butcher W. Influence of environmental contamination with PCBs on human health. Environ Geochem and Health. 2001;23(4):313-28.

78. Hardell L, van Bavel B, Lindström G, Carlberg M, Eriksson M, Dreifaldt AC, et al. Concentrations of polychlorinated biphenyls in blood and the risk for testicular cancer. Int J Androl. 2004;27(5):282-90.

79. Lovett GM, Bowser JJ, Edgerton ES. Atmospheric deposition to watersheds in complex terrain. Hydrol Process. 1997;11:645-54

80. Witczak A. AbdelGawad H. Comparison of organochlorine pesticides and polychlorinated biphenyls residues in vegetables, grain and soil from organic and conventional farming in Poland J Environ Sci Health B. 2012;47(4):343-54.

81. Ferrante MC, Fusco G, Monnolo A, Saggiomo J, Guccione J, Mercogliano R, Clausi MT. Food contamination by PCBs and waste disposal crisis: evidence from goat milk in Campania (Italy). Chemosphere. 2017:86:396-404.

82. Gasecka M, Drzewiecka K, Stachowiak J, Siwulski M, Goliěski P, Sobieralski K, Golak I. Degradation of polycyclic aromatic hydrocarbons (PAHs) by spent mushroom substrates of Agaricus bisporus and lentinula edodes. Acta Sci Pol-Hortoru. 2012;1 1(4):39-46.

83. Sablayrolles C, Silverstre J, Lhoutelier C, Montrejaud-Vignoles M. Phthalates uptake by tomatoes after biosolids application: worst case and operational practice in greenhouse conditions. Fresen Environ Bull. 2013;22(4A):1061-9.

84. Oleszczuk P, Baran S. Polyaromatic hydrocarbons in rhizosphere soil of different plants: effect of soil properties, plant species, and intensity of anthropogenic pressure. Commun Soil Sci Plan. 2007;38(1-2):171-88.

85. Bizkarguenaga E, Zabaleta I, Mijangos L, Iparraguirre A, Fernández LA, Prieto A, Zuloaga O. Uptake of perfluorooctanoic acid, perfluorooctane sulfonate and perfluorooctane sulfonamide by carrot and lettuce from compost amended soil. Sci Total Environ. 2016;571:444-51.

86. Khan S, Cao Q. Human health risk due to consumption of vegetables contaminated with carcinogenic polycyclic aromatic hydrocarbons. J Soil Sediment. 2011. https://doi.org/10.1007/s11368-011-0427-3.

87. Valdés R, Ochoa J, Franco JA, Bañón S. Saline irrigation scheduling for potted geranium based on soil electrical conductivity and moisture sensors. Agric Water Manag. 2015:149:123-30.

88. Gupta N, Yadav KK, Kumar V, Kumar S, Chadd RP, Kumar A. Trace elements in soil-vegetables interface: translocation, bioaccumulation, toxicity and amelioration — a review. Sci Total Environ. 2019;651(2):2927-42.

89. Jan FA, Ishaq M, Khan S, Ihsanullah I, Ahmad I, Shakirullah M. A comparative study of human health risks via consumption of food crops grown on wastewater irrigated soil (Peshawar) and relatively clean water irrigated soil (lower Dir). J Hazard Mater. 2010;179:612-21.

90. Singh S, Parihar P, Singh R, Singh VP, Prasad SM. Heavy metal tolerance in plants: role of transcriptomics, proteomics, metabolomics, and ionomics. Science. 2015:6:1143.

91. Olowoyo JO, Van Heerden E, Fischer JL, Baker C. Trace metals in soil and leaves of Jacaranda mimosifolia in Tshwane area South Africa. Atmos Environ. 2010;44:1826-30.

92. Nabulo G, Black CR, Young SD. Trace metal uptake by tropical vegetables grown on soil amended with urban sewage sludge. Environ Pollut. 2011;159(2):368-76.

93. Lion GN, Olowoyo JO. Urban farming as a possible source of trace metals in human diets. S Afric J Sci. 2015;112(1/2):1-6.

94. Tomašević M, Aničić M. Trace element content in urban tree leaves and sem-edax characterization of deposited particles. Phys Chem Technol. 2018:8(1):1-13.

95. Rafiq MT, Aziz R, Yang XE, Xiao WD, Stofella PJ, Saghir A, Azam M, Li TQ. Phyto-availability of cadmium (Cd) to Pak Choi (Brassica chinensis L.) grown in Chinese soils: a model to evaluate the impact of soil $\mathrm{Cd}$ pollution on potential dietary toxicity. PLOS ONE. 2014;9(11):e111-e461. https://doi.org/10.1371/journal.pone.0111461.

96. Xu L, Wang Y, Liu W, Wang J, Zhu X, Zhang K. De novo sequencing of root transcriptome reveals complex cadmium-responsive regulatory networks in radish (Raphanus sativus L.). Plant Sci. 2015;236:313-23.

97. Yang Y, Song Y, Scheller HV, Ghosh A, Ban Y, Chen H, Tang M. Community structure of Arbuscular mycorrhizal fungi associated with Robinia pseudoacacia in uncontaminated and heavy metal contaminated soils. Soil Biol Biochem. 2015;86:146-58.

98. Yadav SK. Heavy metals toxicity in plants: an overview on the role of glutathione and phytochelatins in heavy metal stress tolerance of plants. S Afr J Bot. 2018:76(2):167-79.

99. Qureshi AS, Hussain MI, Ismail S, Khan QM. Evaluating heavy metal accumulation and potential health risks in vegetables irrigated with treated wastewater. Chemosphere. 2016;163:54-61.

100. Nookabkaew S, Rangkadilok N, Prachoom N, Satayavivad J. Concentrations of trace elements in organic fertilizers and animal manures and feeds and cadmium contamination in herbal tea (Gynostemma pentaphyllum Makino). J Agric Food Chem. 2016;64(16):3119-266.

101. Kirchmann H, Börjesson G, Kätterer T, Cohen Y. From agricultural use of sewage sludge to nutrient extraction: a soil science outlook. Ambio. 2017;46(2):143-54.

102. Mortvedt JJ. Heavy metal contaminants in inorganic and organic fertilizers. In: Rodriguez-Barrueco C, editor. Fertilizers and environment. Dordrecht: Springer; 1996. p. 66. https://doi. org/10.1007/978-94-009-1586-2_2.

103. Gupta G, Charles S. Trace elements in soils fertilized with poultry litter. Poult Sci. 1999;78:1695-8.

104. Zhao FJ, Moore KL, Lombi E, Zhu YG. Imaging element distribution and speciation in plant cells. Trends Plant Sci. 2014;19:183-92.

105. Tyagi SK, Datta PS, Sharma PK, Kulshresth S. Nitrate and fluoride contamination in groundwater under intensive agricultural land use. Asian J Water Environ Pollut. 2009;6(2):81-6.

106. Singh A, Sharma RK, Agrawal M, Marshall FM. Risk assessment of heavy metal toxicity through contaminated vegetables from waste water irrigated area of Varanasi India. Trop. Ecol. 2010;51(2S):375-87.

107. Nabulo G, Young SD, Black CR. Assessing risk to human health from tropical leaf vegetables grown on contaminated urban soils. Sci Total Environ. 2010;408:5338-511.

108. Östman M, Fick J, Näsström E, Lindberg RH. Snapshot of illicit drug use in Sweden acquired through sewage water analysis. Sci Total Environ. 2014;472:862-71.

109. Khan JA, Iabal Z, Rahman SU, Farzana K, Khan A. Prevalence and resistance pattern of Pseudomonas aeruginosa against various antibiotics. Pak J Pharm Sci. 2008:21(3):311-5.

110. Weldegebriel Y, Chandravanshi BS, Wondimu T. Concentration levels of metals in vegetables grown in soils irrigated with river-water in Addis Ababa Ethiopia. Ecotoxicol Environ Saf. 2012;77:57-63.

111. Wang Y, Chen YC, Li ZP. Contamination pattern of heavy metals in Chinese urban soils. Environ Chem. 2012:31:763-70.

112. Food and Agriculture Organization of the United Nations (FAO), World Health Organization (WHO). Evaluation of certain food additives and 
contaminants. In: Proceedings of the seventy-third meeting of the joint expert committee on food additives JECFA, technical report series 960, Geneva, Switzerland, 8-17 June 2011.

113. Liu W, Sun W, Borthwick AGL, Ni J. Comparison on aggregation and sedimentation of titanium dioxide, titanate nanotubes and titanate nanotubes- $\mathrm{TiO}_{2}$ : influence of $\mathrm{pH}$, ionic strength and natural organic matter. Colloids Surf A Physicochem. 2013;434:31928.

114. Nabulo G, Oryem-Origa H, Diamond M. Assessment of lead, cadmium, and zinc contamination of roadside soils, surface films, and vegetables in Kampala City Uganda. Environ Res. 2006;101:42-52.

115. Khan SA, Mulvaney RL, Ellsworth TR, Boast CW. The myth of nitrogen fertilization for soil carbon sequestration. J Environ Qual. 2007:36:1821-32.

116. Bourioug M, Alaoui-Sehmer L, Laffray X, Benbrahim M, Aleya L, Alaoui-Sossé $B$. Sewage sludge fertilization in larch seedlings: effects on trace metal accumulation and growth performance. Ecol Eng. 2015;77:216-24

117. Bigdeli M, Seilsepour M. Investigation of metals accumulation in some vegetables irrigated with waste water in Shahre Rey-Iran and toxicological implications. Am Eurasian J Agric Environ Sci. 2008;4(1):86-92.

118. Kelessidisa A, Stasinakis AS. Comparative study of the methods used for treatment and final disposal of sewage sludge in European countries. Waste Manage. 2012;32:1186-95.

119. Adekunle I, Olurundare $\mathrm{O}$, Nwange $\mathrm{C}$. Assessments of $\mathrm{Pb}$ levels and daily intakes from green leafy vegetables of southwest Nigeria. Food Sci Nutr. 2009;39(4):413-22.

120. Chary NS, Kamala CT, Raj DSS. Assessing risk of heavy metals from consuming food grown on sewage irrigated soils and food chain transfer. Ecotoxicol Environ Saf. 2007;69(3):513-24.

121. Sithole SC, Mugivhisa LL, Amoo S, Olowoyo JO. Pattern and concentrations of trace metals in mushrooms harvested from trace metalpolluted soils in Pretoria, South Africa. S Afr J Bot. 2016. https://doi. org/10.1016/j.sajb.2016.08.010.

122. Aina WE, Olowoyo JO, Mugivhisa LL, Amoo SO. Effect of different soi amendments on growth performance and levels of copper and zinc in Lycopersicon esculentum. Nat Environ Pollut Technol. 2018;17(1):255-9.

123. León-Cañedo JA, Alarcón-Silvas SG, Fierro-Sañudo JF, RodríguezMontesde Oca GA, Partida-Ruvalcaba L, Díaz-Valdés T, Páez-Osuna F. Mercury and other trace metals in lettuce (Lactuca sativa) grown with two low-salinity shrimp effluents: accumulation and human health risk assessment. Sci Tot Environ. 2019;650:2535-44.

124. Smith RS. A critical review of the bioavailability and impacts of heavy metals in municipal solid waste composts compared to sewage sludge. Environ Int. 2009;35(1):142-56.

125. Alia N, Sardar K, Said M, Salma K, Sadia A, Sadaf S, Toqeer A, Miklas S. Toxicity and bioaccumulation of heavy metals in spinach (Spinacia oleracea) grown in a controlled environment. Int J Environ Res Public Health. 2015;12:7400-16.
126. Pathak C, Chopra AK, Srivastava S. Accumulation of heavy metals in Spinacia oleracea irrigated with paper mill effluent and sewage. Environ Monit Assess. 2013;185(9):7343-735.

127. Mugivhisa LL, Olowoyo JO. Accumulation pattern of trace metals in Spinacia oleracea harvested from soil treated with urine in comparison with other soil amendments in Pretoria, South Africa. Int J Recycl Org Waste Agric. 2017:6(2):133-41.

128. Kihampa C, Mwegoha WJS, Shemdoe RS. Heavy metals concentrations in vegetables grown in the vicinity of the closed dumpsite. Int J Environ Sci. 2011;2:2.

129. Uriah LA, Shehu U. Environmental risk assessment of heavy metals content of municipal solid waste used as organic fertilizer in vegetable gardens on the Jos Plateau Nigeria. Am J Environ Prot. 2014;3(6-2):1-13.

130. Antonious GF, Kochhar TS, Coolong T. Yield, quality, and concentration of seven heavy metals in cabbage and broccoli grown in sewage sludge and chicken manure amended soil. J Environ Sci Health [A]. 2012. https://doi.org/10.1080/03601234.2012.676509.

131. Sah SK, Shriwastay CP, Acharya BS, Khanal B, Shah SC. Heavy metals accumulation in cauliflower (Brassica Oleracea L. var. Botrytis) grown in brewery sludge amended sandy loam soil. Int J Agric Sci Technol (IJAST). 2014. https://doi.org/10.14355/ijast.2014.0203.01.

132. Ez-zarhouny D, Hbaiz EM, Lebkiri M, Lebkiri A, Rifi EH. Evaluation de l'impact des eaux usees d'une station d'epuration sur le developpement de la betterave rouge (Beta vulgaris L.) cultivee sur deux sols differents. Larhyss J. 2015;23:105-15.

133. Lima B, Tapia A, Luna L, Fabani MP, Schmeda-Hirschmann G, Podio NS, Wunderlin DA, Feresin GE. Main flavonoids, DPPH activity, and metal content allow determination of the geographical origin of propolis from the province of San Juan (Argentina). J Agric Food Chem. 2009;57(7):2691-8.

134. Almuktar SA, Abed SNM. Contaminations of soil and two Capsicum annuum generations irrigated by reused urban wastewater treated by different reed beds. Int J Environ Res Public Health. 2018;5(8):1776.

135. Antonious GF, Kochhar TS, Coolong T. Yield, quality, and concentration of seven heavy metals in cabbage and broccoli grown in sewage sludge and chicken manure amended soil. J Environ Sci Health A Toxic. 2016:47(13):1955-65.

136. Bvenura C, Afolayan JA. Heavy metal contamination of vegetables cultivated in home gardens in the Eastern Cape. S Afr J Sci. 2012;108(9-10):1-6.

137. Odai SN, Mensah E, Sipitey D, Ryo S, Awuah E. Heavy metals uptake by vegetables cultivated on urban waste dumpsites: case study of Kumasi Ghana. Res J Environ Toxicol. 2008;2(2):92-9.

\section{Publisher's Note}

Springer Nature remains neutral with regard to jurisdictional claims in published maps and institutional affiliations.

\section{Submit your manuscript to a SpringerOpen ${ }^{\circ}$ journal and benefit from:}

- Convenient online submission

- Rigorous peer review

- Open access: articles freely available online

- High visibility within the field

- Retaining the copyright to your article

Submit your next manuscript at $\boldsymbol{\nabla}$ springeropen.com 